\title{
Relation between agenesis and shape anomaly of maxillary lateral incisors and canine impaction
}

Anísio Bueno de Carvalho', Rogério Heladio Lopes Motta² ${ }^{2}$ Eliane Maria Duarte de Carvalho³

Objective: The purpose was to obtain information about the relation between agenesis and shape anomaly of maxillary lateral incisors and canine impaction. Methods: Seventy-three patients with canine impaction and 73 control patients, without canine impaction, were evaluated. The mesiodistal distances of the maxillary lateral incisors adjacent to the impacted canines and the correspondent mandibular lateral incisors were measured. The adjacent lateral incisors were classified in: 1 - absent, 2 - small, 3 - peg-shaped, 4 - standard. Results: The results showed that among the patients with impacted canines, there were 21 anomalous teeth (small and pegshaped) and among the control patients there were only three small and peg-shaped teeth, with a statistically significant difference $(\mathrm{p}=0.001)$. No patients were found with impacted canines and absent lateral incisors. Conclusion: It was concluded that in patients with anomalous lateral incisors (small and peg-shaped) there is a probability to present impacted canines and this must be considered.

Keywords: Incisors. Canine. Agenesis.

Objetivo: o objetivo foi obter informação sobre a relação existente entre a agenesia e/ou anomalia de forma de incisivos laterais superiores e impacção de caninos. Métodos: foram avaliados 73 pacientes com impacção de caninos e 73 pacientes controle, sem impacção de caninos. Foram medidas as distâncias mesiodistais dos incisivos laterais superiores adjacentes aos caninos impactados e os incisivos laterais correspondentes inferiores. Os incisivos laterais adjacentes foram classificados em: 1 - ausentes; 2 - pequenos; 3 - conoides; 4 - normais. Resultados: os resultados mostraram que no grupo de pacientes com caninos impactados foram encontrados 22 dentes anômalos (pequenos e conoides), e no grupo controle apenas três dentes pequenos e conoides, sendo uma diferença estatisticamente significativa $(\mathrm{p}=0,001)$. Não foram encontrados pacientes com canino impactado e incisivo lateral ausente. Conclusão: concluiu-se que nos pacientes com incisivos laterais anômalos (pequenos e conoides), a probabilidade de apresentarem caninos impactados existe e deve ser considerada..

Palavras-chave: Incisivo. Dente canino. Anodontia.

${ }^{1}$ Professor and Coordinator of the Specialization Course in Orthodontics, São Leopoldo Mandic Dental Research Center - Belo Horizonte unit.

${ }^{2}$ Professor, São Leopoldo Mandic, Dental Research Center - Campinas unit.

${ }^{3}$ Professor and Coordinator of the Specialization Course in Orthodontics, São Leopoldo Mandic Dental Research Center - Belo Horizonte unit.

» The author reports no commercial, proprietary or financial interest in the products or companies described in this article.

» Patients displayed in this article previously approved the use of their facial and intraoral photographs.
How to cite this article: Carvalho AB, Motta RHL, Carvalho EMD. Relation between agenesis and shape anomaly of maxillary lateral incisors and canine impaction. Dental Press J Orthod. 2012 Nov-Dec;17(6):83-8.

Submitted: March 09, 2009 - Revised and accepted: October 20, 2010

Contact address: Anísio Bueno de Carvalho

Rua Claudio Manoel, 197, Apto 1103 - Bairro Funcionários - Belo Horizonte - Brazil CEP: 30140-100 - E-mail: anisio@uai.com.br / anisiocarvalho@taskmail.com.br 


\section{INTRODUCTION}

The impaction of upper canine is a frequent event. The diagnosis and treatment of this issue usually requires the expertise and cooperation of the gerenal practitioner, pediatric dentist, dental surgeon, periodontist and orthodontist. ${ }^{1,6}$

Palatal displacement of one or both canines have been reported as affecting 1-3\% of the population. . $-7,10,11$ When there is a late diagnosis of this condition, the treatment often implicates exposure and subsequent traction and alignment in a period of protraction. ${ }^{19,20}$

It would be preferable if the condition could be diagnosed in an early stage so that interceptive measures could be implemented. ${ }^{1,10,19,20}$ In $70-85 \%$ of these impactions, the canine is located palatally, while in the remaining, $15-30 \%$ the canine is labially impacted. ${ }^{20,27}$ Palatal and labial impactions are considered completely different entities. Labial impaction of the canine is thought to be a type of crowding. ${ }^{11}$ The etiology of canine palatal impaction is not very clear. Some authors believe that, unlike the labial impaction, the excessive space in the maxillary arch could lead to palatal impaction of the canine for allowing the canine to cross behind the labial surface. ${ }^{13,35}$

Jacoby $\mathrm{H}^{20}$ reported that $85 \%$ of the palatal impacted canines have sufficient space for eruption. Others accused the congenital absence or the presence of small lateral incisors for canine impaction. The mesiodistal crown width of the maxillary and mandibular incisors have been reported to be significantly smaller in patients with palatal canine impaction. ${ }^{1,4-7,10,11,12,14}$ The root length of lateral incisors adjacent to palatally displaced canines was also reported as responsible for the displacement of the palatally impacted maxillary canines. ${ }^{8}$

To correct this malocclusion, the most common preventive treatment is to extract the deciduous canine expecting that the permanent canine will adjust its position by itself. ${ }^{31}$ Two studies reported the success with this treatment, finding favorable eruption in $78 \%$ of the individuals, by Ericson and Kurol, ${ }^{17}$ and in $62 \%$ of the individuals, by Power and Short. ${ }^{30}$

The purpose of this study was to evaluate the existing relation between impaction of upper ca- nine and a) shape anomaly of maxillary lateral incisors; b) agenesis of maxillary lateral incisors.

\section{MATERIAL AND METHODS}

The present research was developed after approval of the Research Project in the Council of Ethics and Research of the São Leopoldo Mandic Dental Research Center, under the number 07/0423.

\section{Material}

It started from a sample of 3.500 pretreatment radiographs from the file of the patients of São Leopoldo Mandic Dental Research Center. From this file, two groups were obtained, with 73 patients each.

- The experimental group with 73 radiographs of maxillary canine impaction (Figs 1 to 6):

» Inclusion Criteria: 1) Chronological age of 13 years minimum; 2) Panoramic radiographs with presence of impacted upper canine; 3) Patients that presented all teeth in the dental arch, except in cases of agenesis of maxillary lateral incisors; 4) Patients that did not present resin restoration nor enamel fractures of the maxillary and mandibular lateral incisors.

» Exclusion criteria: 1) All panoramic radiographs with lack of distinctness and good quality; 2) Patients under the age of 13 years; 3) Patients that presented maxillary or mandibular lateral incisors with enamel fracture or resin restoration; 4) Documentation that showed radiographs, photographs and study casts in poor condition.

- Control group with 73 radiographs with no retained canines.

» Inclusion criteria: 1) Chronological age of 13 years minimum; 2) Patients with all teeth erupted, except those that presented maxillary lateral incisors agenesis; 3) Patients with no kinds of restoration nor fractures of the maxillary and mandibular lateral incisors.

» Exclusion criteria: 1) All panoramic radiographs with lack of resolution and quality; 2) Patients under the age of 13 years; 3) Patients that presented maxillary or mandibular lateral incisors with enamel fracture or resin restoration; 4) Documentation that showed radiographs, photographs and study casts in poor condition. 

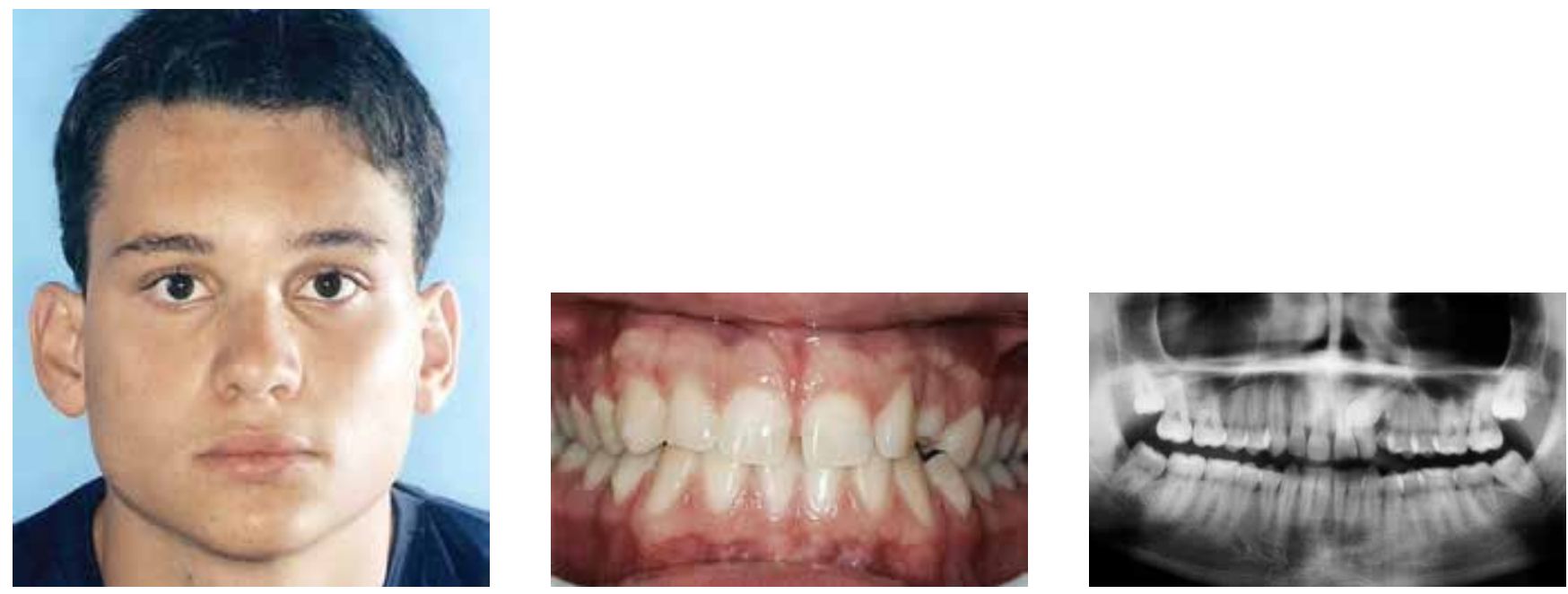

Figure 1 - Patient with no anomaly on the maxillary lateral incisor.


Figure 2 - Patient with peg-shaped maxillary lateral incisor.

\section{Methods}

The presence of maxillary canine retention was evaluated, defining as retained canines those that presented the following criteria:

» 1) The impacted canine should have a root apex completely formed, with no sign of eruption inside the oral cavity; 2 ) only the canines with lingual impaction were analyzed, confirmed by the periapical radiographs on Clark's positioning. After the radiographic diagnosis, the absent or anomalous lateral incisors were evaluated according to the studies of Bot, Salmon ${ }^{9}$; Becker, Smith and Behar ${ }^{7}$, and classified as:

»1) Absent; 2) Peg-shaped, with larger mesiodistal width at the cervical margin; 3) Small, with mesiodistal width equal or smaller than its mandibular counterpart; 4) Standard, with mesiodistal width larger than its mandibular counterpart. 


\section{RESULTS}

The results from the present work are displayed in Tables 1 and 2.

\section{DISCUSSION}

The prevalence of patients with impacted canines in this sample was $2.08 \%$, according to the work of Hechler, ${ }^{19}$ Richardson and Russel, ${ }^{31}$ Leifert and Jonas, ${ }^{21}$ Mesotten and Naert, ${ }^{23}$ and Sacerdoti and Baccetti. ${ }^{33}$ There was a greater prevalence of the female gender, which confirms the work of Becker, ${ }^{16}$ who found a proportion of two women for each man with impacted canines. ${ }^{7,13,16,20}$ These results can be explained by the prevalence of anomalies in maxillary lateral incisors, that is mostly found in women than in men.

Statistically significant results were found when association tests were performed between teeth with shape anomaly and presence of impacted canine ( $\mathrm{p}=0.001)$. These findings concur with the work of Becker, ${ }^{7}$ Jacoby, ${ }^{20}$ Becker, ${ }^{8}$ Brin et al, ${ }^{11}$ Becker, ${ }^{3}$ Peck, ${ }^{28}$ Becker, ${ }^{5}$ Langberg, ${ }^{22}$ Becker, ${ }^{6}$ Sacerdoti and Baccetti, ${ }^{33}$ Paschos et al, ${ }^{27}$ Oliver et al, ${ }^{26}$ Mossey et $\mathrm{al}^{24}$ The reason brought up in the literature about this association is that the excessive space in the maxilla could be a contributory fac-

Table 1 - Prevalence of impacted canines by tooth size with $p$ value to test variation between the groups (Fisher's exact test).

\begin{tabular}{cccccc|} 
Tooth & \multicolumn{2}{c}{ Group } & OR & CI 95\% & p value* $^{\star}$ \\
& Control & Experimental & & & \\
Standard & 70 & 52 & 1.00 & -- & \\
& $95.8 \%$ & $71.2 \%$ & & & \\
Small & 2 & 10 & & & \\
& $2.8 \%$ & $13.7 \%$ & 4.72 & $(1.5 ; 30.68)$ & 0.003 \\
& 1 & 11 & & & \\
Peg-shaped & $1.4 \%$ & $15.1 \%$ & 6.44 & $(1.25 ; 17.81)$ & \\
\hline
\end{tabular}

* Statistically significant. tor in the palatal displacement, for it enables sufficient space for the canine to move and deviate from its direction for labial eruption. Also, the absence of guidance from the lateral incisor, allows a new course to a way further down and to the palatal side. Another reason is the possible biological relation between impacted canine and tooth size reduction. The theory is that anomalies of number, tooth size reduction and impacted canine are three of the covariant in a genetically controlled complex dental disorders occurring frequently combined instead of an anomalous lateral incisor having a mechanical effect over the canine position. It is possible that the gene or genes responsible for the control of the eruption and consequently for the palatal displaced canines are connected to the gene or genes causative of hypodontia/incisor agenesis. The presence of teeth smaller than the average in the sample with retained canines support previous reports that palatal canine impaction is developed in patients with appropriate dentoalveolar arch space. Saiar et al ${ }^{34}$ pointed that canine malposition occurs most frequently in cases with regular arch shape and sufficient space. Bass ${ }^{2}$ noticed that $36 \%$ of the patients with impacted canines had non-crowded arch, but all of the 10 patients in the experimental group

Table 2 - Prevalence of impacted canines by tooth size with $p$ value to test variation between the groups (Fisher's exact test).

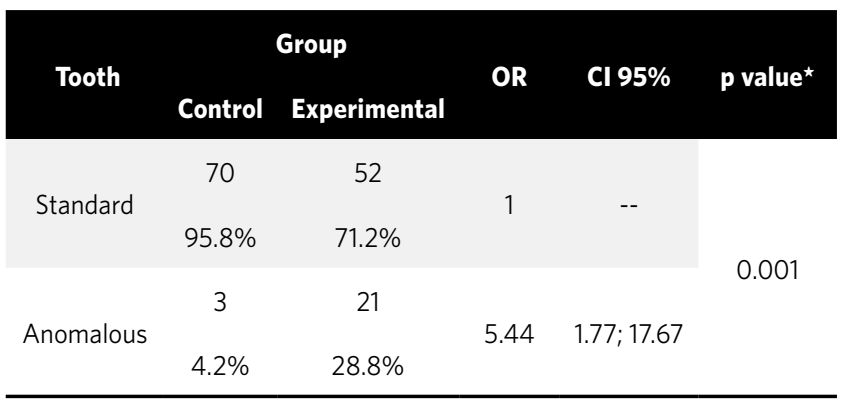

* Statistically significant. 
with buccally impacted canines had crowding. Eighty five percent of the patients with impacted canines have sufficient space for canine eruption in the arch, according to Jacoby. ${ }^{20}$ The reduced size of the tooth in the group of palatal impaction and in the control group correspond to the findings of Nagpal et al, ${ }^{25}$ which reported that, on average, the mesiodistal diameter of the crown of the maxillary incisors was smaller in the sample of canine palatal displacement than in the control group. Despite not all the previous studies did really measure tooth size, similar observations and statistics suggesting that impacted canine is not associated to maxillary crowding supports our findings of tooth size reduction associated to this anomaly. Brenchley and Oliver, ${ }^{10}$ disagreed with the statement that there is an association between impacted canine and maxillary lateral incisor anomaly. However, in their work, the analyzed sample had only 33 patients with unilateral impacted canine, and the control was done with the maxillary lateral incisor of the opposite side of the impacted canine. Indeed, size differences were not found between them, although, there was no comparison with a control group, as in the other works. When the possible relation between absent or anomalous lateral incisors and palatal positioned canine was investigated, it was clear that there was an association. These observations add support to the relation between the two events. However, more studies must be performed to discover the reason for this phenomenon.

Is the cause only local, only genetic or a combination of factors? The current findings, relating impacted canine to the occurrence of widespread size reduction, are coherent with the increasing idea that there is a complex dental disorder genetically controlled, that frequently occurs in combination. Besides tooth size reduction and impacted canine, other dental anomalies in this complex genetic tracing as hypodontia, infraocclusion, late eruption, ectopic eruption of permanent first molars and certain canine transpositions share some common genetic control. ${ }^{15,16,18,28,29}$ Thus, the appearance of small permanent incisors in the initial mixed dentition, especially combined with some of the other associated dental anomalies, could be a useful indicator of future occurrence of impacted canines. ${ }^{15,16,18,25,29,32,36}$

It was concluded in this work that every patient that presents agenesis or shape anomaly of maxillary lateral incisor must be analyzed in advance through specific examination, for they demonstrate strong tendency to present impacted upper canines. 


\section{REFERENCES}

1. Al-Nimri K, Gharaibeh T. Space conditions and dental and occlusal features in patients with palatally impacted maxillary canines: an aetiological study. Eur J Orthod. 2005;27(5):461-5.

2. Bass TB. Observations on the misplaced upper canine tooth. Dent Pract Dent Rec. 1967;18(1):25-33.

3. Becker A. In defense of the guidance theory of palatal canine displacement. Angle Orthod. 1995;65(2):95-8.

4. Becker A, Chaushu S. Dental age in maxillary canine ectopia. Am J Orthod Dentofacial Orthop. 2000;117(6):657-62

5. Becker A, Gillis I. The etiology of palatal displacement of maxillary canines. Clin Orthod Res. 1999;2(2):62-6.

6. Becker A, Sharabi S, Chaushu S. Maxillary tooth size variation in dentitions with palatal canine displacement. Eur J Orthod. 2002;24(3):313-8.

7. Becker A, Smith $P$, Behar R. The incidence of anomalous maxillary lateral incisors in relation to palatally-displaced cuspids. Angle Orthod. 1981;51(1):24-9.

8. Becker A, Zilberman Y, Tsur B. Root length of lateral incisors adjacent to palatallydisplaced maxillary cuspids. Angle Orthod. 1984;54(3):218-25.

9. Bot PL, Salmon D. Congenital defects of the upper lateral incisors (ULI): condition and measurements of the other teeth, measurements of the superior arch, head and face. Am J Phys Anthropol. 1977;46(2):231-43

10. Brenchley Z, Oliver RG. Morphology of anterior teeth associated with displaced canines. Br J Orthod. 1997;24(1):41-5.

11. Brin I, Becker A, Shalhav M. Position of the maxillary permanent canine in relation to anomalous or missing lateral incisors: a population study. Eur J Orthod. 1986;8(1):12-6.

12. Camilleri S. Maxillary canine anomalies and tooth agenesis. Eur J Orthod. 2005;27(5):450-6.

13. Chaushu S, Sharabi S, Becker A. Dental morphologic characteristics of normal versus delayed developing dentitions with palatally displaced canines. Am J Orthod Dentofacial Orthop. 2002;121(4):339-46

14. Chaushu S, Sharabi S, Becker A. Tooth size in dentitions with buccal canine ectopia. Eur J Orthod. 2003;25(5):485-91.

15. Das P, Stockton DW, Bauer C, Shaffer LG, D'Souza RN, Wright T, et al. Haploinsufficiency of PAX9 is associated with autosomal dominant hypodontia. Hum Genet. 2002;110(4):371-6.

16. De Conto FSER, Scarel R, Peres RC. Investigação de polimorfismo na região promotora do gene BMP4 em indivíduos com agenesia dental. Rev Fac Odontol Passo Fundo. 2004;9(1):7-11.

17. Ericson S, Kurol J. Resorption of maxillary lateral incisors caused by ectopic eruption of the canines. A clinical and radiographic analysis of predisposing factors. Am J Orthod Dentofacial Orthop. 1988;94(6):503-13.

18. Han D, Gong $Y$, Wu H, Zhang X, Yan M, Wang $X$, et al. Novel EDA mutation resulting in $\mathrm{X}$-linked non-syndromic hypodontia and the pattern of EDA-associated isolated tooth agenesis. Eur J Med Genet. 2008;51(6):536-46.
19. Hechler SL. Impacted canines: diagnosis, prognosis, and treatment. J Kans Dent Assoc. 1987;71(2):18-21

20. Jacoby $\mathrm{H}$. The etiology of maxillary canine impactions. Am J Orthod 1983:84(2):125-32

21. Leifert S, Jonas IE. Dental anomalies as a microsymptom of palatal canine displacement. J Orofac Orthop. 2003;64(2):108-20

22. Langberg BJ, Peck S. Tooth-size reduction associated with occurrence of palatal displacement of canines. Angle Orthod. 2000;70(2):126-8.

23. Mesotten K, Naert I, van Steenberghe D, Willems G. Bilaterally impacted maxillary canines and multiple missing teeth: a challenging adult case. Orthod Craniofac Res. 2005;8(1):29-40.

24. Mossey PA, Campbell HM, Luffingham JK. The palatal canine and the adjacent lateral incisor: a study of a west of Scotland population. $\mathrm{Br} J$ Orthod. 1994;21(2):169-74.

25. Nagpal A, Pai KM, Sharma G. Palatal and labially impacted maxillary canineassociated dental anomalies: a comparative study. J Contemp Dent Pract. 2009;10(4):67-74

26. Oliver RG, Mannion JE, Robinson JM. Morphology of the maxillary lateral incisor in cases of unilateral impaction of the maxillary canine. Br J Orthod. 1989:16(1):9-16.

27. Paschos E, Huth KC, Fässler H, Rudzki-Janson I. Investigation of maxillary tooth sizes in patients with palatal canine displacement. J Orofac Orthop. 2005;66(4):288-98

28. Peck S, Peck L, Kataja M. Concomitant occurrence of canine malposition and tooth agenesis: evidence of orofacial genetic fields. Am J Orthod Dentofacial Orthop. 2002;122(6):657-60

29. Pereira TV, Salzano FM. Natural selection and molecular evolution in primate PAX9 gene, a major determinant of tooth development. Proc Natl Acad Sci USA 2006;103(15):5676-81.

30. Power SM, Short MB. An investigation into the response of palatally displaced canines to the removal of deciduous canines and an assessment of factors contributing to favorable eruption. Br J Orthod. 1993;20(3):15-23.

31. Richardson G, Russell KA. A review of impacted permanent maxillary cuspidsdiagnosis and prevention. J Can Dent Assoc. 2000;66(9):497-501.

32. Roos A, Eggermann T, Zschiesche S, Midro A, Schwanitz G. Abnormalities in tooth morphology, structure and dentition in two children with chromosome aberrations. Translocation trisomy 13 and trisomy 21. Adv Med Sci. 2008;53(1):17-20.

33. Sacerdoti R, Baccetti T. Dentoskeletal features associated with unilateral or bilateral palatal displacement of maxillary canines. Angle Orthod. 2004;74(6):725-32.

34. Saiar M, Rebellato J, Sheats RD. Palatal displacement of canines and maxillary skeletal width. Am J Orthod Dentofacial Orthop. 2006;129(4):511-9.

35. Schindel RH, Duffy SL. Maxillary transverse discrepancies and potentially impacted maxillary canines in mixed-dentition patients. Angle Orthod. 2007;77(3):430-5.

36. Wise GE. Cellular and molecular basis of tooth eruption. Orthod Craniofac Res. 2009;12(2):67-73 